\title{
ІСТОРИЧНИЙ АНАЛІЗ ЙОРК-АНТВЕРПЕНСЬКИХ ПРАВИЛ
}

\author{
ШИШИКІН Сергій Миколайович - аспірант відділу проблем цивільного, \\ трудового і підприсмницького права Інституту держави і права ім. В. М. Корецького \\ НАН України \\ ORCID ID: https://orcid.org/0000-0002-3964-5434 \\ УДК: 341.225.5:341.9:347.796 \\ DOI 10.32782/NP.2021.3.22
}

В статье представлен исторический анализ Йорк-Антверпенский правил. Основное внимание в статье уделено предпосъилке и истории создания Йорк-Антверпенских правил, подчеркнута большая роль субъектов международного частного морского права в унибикащии института общей аварии, а также в статье рассмотрень положительное и отрицательное отношение субъектов международного частного морского права, возникшие во время унибикации института общей аварии. В результате исследования материалов бъл подчеркнут особъй статус и уникальность Йорк-Антверпенских правил, предпосълки создания, изменения и развития Правил, их значительная роль в регулировании института общей аварии в течение большого промежутка времени.

Ключевъе слова: Йорк-Антверпенские правила, Йоркские правила, унибикачия института общей аварии, конберениия в Глазго 1860 году.

Постановка проблеми

Йорк-Антверпенські правила $\epsilon$ унікальним випадком кодифікації норм міжнародного приватного морського права. На сьогодні ці правила мають велике значення для регулювання інституту загальної аварії у світі. Однак, у різні періоди свого існування цей міжнародний договір міг отримати зовсім інший розвиток і його роль у наші дні могла бути іншою.

\section{Стан дослідження проблеми}

Історичним аналізом Йорк-Антверпенських правил, як джерела міжнародного приватного морського права, займалися такі вчені, як Р. І. Акімова, К. І. Александрової, I. С. Жиліна, Жульэн Крут, Г. Г. Іванова, А. А. Маковська, А. А. Маковского, В. Ф. Мешера, Р. Р. Оберга, О. С. Переверзєва, Г. Р. Рудольфа, Мохд Замани Ахмад, Алгантурк Аайт та інші.

\section{Мета і завдання дослідження}

Проведення історичного аналізу ЙоркАнтверпенських правил, визначення особливостей цього джерела міжнародного приватного морського права.

Виклад основного матеріалу

Початком спроб кодифікації норм, якими регулюється інститут загальної аварії вважають початок 1860 р. року, оскільки саме в цей рік Алойд (провідний ринок світового страхування спеціалістів) [1], асоціацією страховиків Ліверпуля і іншими впливовими комерційними організаціями було зроблено подання Національної асоціації для сприяння суспільних наук у Аондоні про необхідність вжити дії, що пов'язані з узагальненням правил про загальну аварію у світі. У відповідь Національна асоціація звернулася 3 травня 1860 р. до всіх морських держав Європи та США 3 циркулярним листом, під яким підписались, крім президента асоціації, керівники 
англійських торгових палат різних міст, асоціаціями страховиків і судновласників.

На конференції в Глазго, яка була відкрита 25 вересня 1860 р., було прийнято дві резолюції та вирішено, що має бути дано 6 місяців для розробки питання з моменту поширення проекту закону до моменту скликання наступної конференції. Проєкт закону поширювався у квітні 1862 р. одночасно із запрошенням на збори для його обговорення в Лондоні, які були намічені на 6 червня того ж року. Запрошення потрапило в $\curlywedge$ лйд лише за кілька днів до 6 червня, і комітет $\curlywedge$ лойд вважав, що абсолютно неможливо обговорити належним чином такий розлогий і складний документ у наданий йому короткий термін. Конференція в Лондоні була відкрита в червні 1862 року, але в результаті опублікованого Алойд листа, адресованого голові, було одноголосно вирішено, що не повинно бути публічного обговорення питань загальної аварії.

Несподівана затримка сталася в складанні проєкту: замість 6-місячного терміну, наміченого конференцією в Глазго для викладу 11 резолюцій у вигляді початкового проєкту закону, пройшло близько 2 років перш ніж проєкт закону побачив світло. Зазначений проект під назвою «Акт, який об'єднує і змінюе закони, що відносяться до пожертвувань і внесків щодо загальної аварії», складався зі 126 пунктів [2, с 40]. Крім того, Конгрес також рекомендував законодавчим органам зацікавлених країн розглянути можливість їх включення до свого національного законодавства, i, до розгляду законодавства, пункти повинні бути внесені до сторін статуту та коносаменти для включення Правил [3].

Критична оцінка цих матеріалів була дана в опублікованих, у січні 1864 р. «Робота міжнародної комісії з загальної аваpiї». Трохи пізніше був скликаний III Міжнародний конгрес 3 загальної аварії в Йорку. У цьому конгресі брали участь представники багатьох торгових палат, судновласників і об'єднань страховиків як англійських, так США і континенту, а також значне число диспашеров. Представник $\curlywedge$ лйд уже на самому початку протес- тував проти наміченого плану робіт, вказуючи, що спроба зводиться не стільки до того, щоб досягти однаковості в питаннях загальної аварії, скільки до того, щоб внести зміни в сучасний англійський закон. ภлойд відповідно відмежувався від робіт конгресу, знайшовши підтримку своєї позиції в секретарі рятувальної асоціації. Ряд делегатів зазначили, що не було потрібно скликати Міжнародну конференцію для зміни англійського закону. Прийнята резолюція підкреслювала, що якщо і мається на меті внесення зміни в англійський закон, то теж саме запропоновано і зробити щодо законів інших торгових країн [2, с 42].

Підсумовуючи результати роботи III Міжнародного конгресу, можна зробити висновок, що поставленої мети не було досягнуто. Однак, на конгресі було узгоджено одинадцять Йоркських правил і резолюція. Стосовно побоювань представників 入лойд, то прийняті «Правила» в певній мірі відобразились на законодавстві Великобританії, однак досить у незначній мірі.

Ідеї щодо узагальнення правил про загальну аварію у світі не змогли реалізуватися ні в результаті конференції в Глазго у 1860p., ні на III Міжнародному конгресі, який був проведений у 1864p. у місті Йорк.

До ідей узагальнення правил про загальну аварію у світі повернулися лише через 10 років, на конгресі Асоціації для реформи і кодифікації міжнародного права в 1876 р. була зроблена доповідь і обрана комісія з представників різних країн для «опрацювання питання загальної аварії». У результаті в 1877 р відбулися збори 68 делегатів в Антверпені з метою зробити подальші серйозні спроби провести цю справу в міжнародному масштабі. Представники ภлойд голосували проти, вказуючи, що вони за введення однаковості в питаннях загальної аварії, але заперечують проти правил, оскільки останні, на їхн думку, значно розширюють сферу застосування загальної аварії. Далі було зазначено, що однаковості простіше досягти шляхом повного анулювання самого принципу загальної аварії. Незважаючи на це, проєкт «Правил» був прийнятий [2, с. 45].у результаті чого «Правила», які були узго- 
джені в Йорку у 1864p., були доповнені, у результаті чого тепер вони мали назву «Йорк-Антверпенські правила» і під цією назвою активно використовується у міжнародному приватному морському праві і наразі.

На конференції в Антверпені у 1877 р. до Йоркських правил було додано дванадцяте правило. Рішення щодо включення правил до коносаментів та страхових полісів було прийнято у 1879 році. У 1881 році на конференції Асоціації з реформування та кодифікації законів націй було повідомлено, що «правила стали майже загальноприйнятими» [4].

Пропозиції зборів поступово стали застосовуватися на практиці, і вже на наступній конференції Асоціації для реформи і кодифікації міжнародного права, що мала місце в Лондоні в 1879 р. було повідомлено, що власники двох п'ятих усього англійського флоту погодилися включати у свої коносаменти і чартери нові правила, що вони прийняті більшою частиною товариств взаємного страхування і що інші англійські страховики, незважаючи на триваючу опозицію з боку Алойд, погодилися включати в поліси умови про застосування правил щодо загальної аварії без додаткової премії. Це загальне визнання правил було, безсумнівно, полегшено рішеннями англійських судів, які взяли принципи, що лежать в основі деяких 3 цих правил, незважаючи на те, що вони розходилися 3 практикою англійських диспашеров. Сприятливі дані були наведені на конференції 1879 р. стосовно і інших країн, так як з'ясувалося, що майже всі судновласники і страховики в Сполучених Штатах, Британських колоніях і в країнах Європейського континенту схвалили нові правила і застосовують їх шляхом включення відповідних застережень у фрахтові договори і страхові поліси.

Після десятирічної практики застосування правил було встановлено, що вони не цілком задовольняють вимогам морської торгівлі і що бажано тому внести в них деякі зміни. Асоціація англійських диспашеров проявила ініціативу в цій справі і опублікувала доповідь, що містить різні зміни правил і доповнення до них для розгляду його на конференції Асоціації для реформи і кодифікації міжнародного права, яка відбулася в 1890 р. в Ліверпулі. На конференції були присутні представники СІІА, Франції, Німеччини, Бельгії та Данії і багато англійських юристів, страховиків (включаючи Алойд) і диспашеров. Робота конференції тривала 4 дні, протягом яких доповідь, яка була представлена Асоціацією диспашеров, була детально розібрана і обговорена, і в результаті були внесені деякі зміни в чинні правила і прийняті нові. Остаточна редакція цих 18 правил стала відома під назвою Йорк-Антверпенских правил 1890 р. які, як це добре знають усі причетні до морської торгівлі особи, з тих пір були прийняті майже повсюдно в усьому світі [2, с. 46].

Йорк-Антверпенські правила, які були прийняті в результаті конференції у 1890 р., стали результатом роботи, яка почалась на конференції в Глазго у 1860p., щодо уніфікації правил загальної аварії в міжнародному масштабі. Будучи диспозитивними нормами, вони не тільки були прийняті у всіх морських країнах, але в деяких державах, де закони щодо загальної аварії не були достатньо повно розроблені, правила, безсумнівно, вплинули на практику диспашеров і доповнювали, майже що підміняючи чинне законодавство щодо загальної аварії [2, с. 48].

У 1903 році на Антверпенській конференції до правил було добавлено нормою щодо розподілу загальної аварії, у випадку іiї виникнення через провину однієї зі сторін морського перевезення [5, с. 163-165.].

Аналіз практики застосування ЙоркАнтверпенских правил було здійснено у 1910 р. на конференції в Лондоні. На конференції в Мадриді в 1913 р. були розглянуті пропозиції про деякі зміни ЙоркАнтверпенских правил. У 1914 році на конференції в Гаазі розроблений і погоджений проєкт нової редакції Йорк- Антверпенских правил.

На конференції в Стокгольмі 1924 р. Йорк-Антверпена правила були переосмислені. Додатково до цифрових були вироблені літерні, основні, правила, які 


\section{Цивільне, підприсмницьке, господарське та трудове право}

повинні застосовуватися в тих випадках, коли цифрові правила не містять відповіді на ці конкретні питання, які виникли при розгляді конкретного випадку. У Правила внесено нову редакцію визначення загальної аварії: «Загальною аварією визначається такий акт, коли і тільки коли були зроблені навмисно і розумно надзвичайні пожертвування або витрати в цілях загального збереження для запобігання від небезпеки майна, яке бере участь у загальному морському підприємстві».

У Брюсселі 1948 року було перероблено правило XXII про нарахування відсотків на загальну аварію. На конференції Міжнародного морського комітету в Амстердамі в 1949 р. були розроблені нові Йорк-Антверпена правила, введені в дію 3 1 січня 1950 p.

У 1969 р постійне бюро Міжнародного морського комітету прийняло рішення про модернізацію Йорк-Антверпенских правил.

Були створені робочі групи для підготовки проєкту змін Правил. На ХХХ конференції Міжнародного морського комітету в Гамбурзі в 1974 році була прийнята нова редакція Йорк-Антверпенских правил. Зміни торкнулися літерного правила «Д», цифрових правил III, IV, V, VI, X, XI, XIII, XVI, XVII, XVIII та XXI.

У 1990 р на конференції Міжнародного морського комітету в Парижі прийнято новий текст правила VI «Рятування».

Таким чином, виникла редакція ЙоркАнтверпена правил 1974 г., змінена в $1990 \mathrm{p}$.

У 1991 р. на Конференції Організації Об'єднаних Націй з торгівлі та розвитку (ЮНКТАД) розглядалося питання про можливість створення міжнародних імперативних правил щодо загальної аварії, однак було прийнято рішення зберегти порядок, при якому відносини, пов'язані 3 загальною аварією, регулюються диспозитивними нормами.

У 1994 р. була прийнята нова редакція Йорк-Антверпенских правил, що відображає сучасні тенденції розвитку торгового мореплавання.

Перегляд Иорк-Антверпенских правил у 2004 р. у порівнянні 3 редакцією
1994 року в Правила були внесені незначні зміни, які істотно не змінили порядок i принципи розподілу збитків щодо загальної аварії. Зокрема, в Правила 2004 року було включено нове Правило XXIII, пов'язане з обчисленням строків позовної давності [6, с. 20-23].

Йорк-Антверпена правила 2004 року не набули широкого використання, тому на практиці, як правило використовувались правила 1994 року, у деяких випадках 1949 року.

Нові правила стали результатом компромісів, укладених у співпраці з корабельними, вантажними та страховими інтересами.

Найбільш суперечливий аспект переговорів стосувався питання про те, як під час загальної аварії слід ставитися до порятунку. 3 одного боку, стверджувалося, що оскільки судно та вантаж мають окремі зобов'язання сплачувати витрати на порятунок, немає необхідності перерозподіляти витрати на порятунок відповідно до загальної аварії. 3 іншого боку, переконливо стверджувалося, що у багатьох випадках коригування загальної аварії показника призвело до значного (і відповідного) перерозподілу між судновими та вантажними інтересами.

Відповідно до Йорк-Антверпенських правил 2016 р. Аварійні збори підлягатимуть перерозподілу лише в загальній аварії за п'ятьма обставинами, викладеними у правилі IV (b).

Нова формула була включена до правил для розрахунку процентної ставки, що допускається до витрат за загальною аварією, і є нові вимоги щодо утримання депозитів готівки регуляторами.

Введені нові терміни. Загальноаварійні вимоги щодо внесків відстрочуються через рік після дати коригування, але не пізніше ніж через 6 років після припинення рейсу.

Для полегшення коригування було внесено ряд детальних поправок. Наприклад, правило В щодо буксиру та буксирування уточнюється та розширюється, щоб охопити ситуації з портом-притулком. Також відбулося певне перевпорядкування 
Правил, щоб зробити послідовність більш логічною.

Через кілька днів після конференції Документальний комітет Балтійської і міжнародної морської ради підтвердив схвалення Йорк-Антверпенських правил 2016 та негайно почав використовувати Правила у своїх стандартних товаросупровідних документах.

Конференція також затвердила керівні принципи Міжнародного Морського Комітету щодо загальної аварії [7].

\section{Висновки}

Йорк-Антверпенські правила $€$ унікальним джерелом міжнародного приватного морського права, яке отримало свою значимість у результаті добровільного використання цих правил суб'єктами міжнародного приватного морського права. Так, як уже зазначалося вище, у певні часи піднімалися питання щодо обов'язкового виконання Йорк-Антверпенських правил. Крім того, ще однією особливістю Правил $\epsilon$ те, що суб'єктами міжнародного приватного морського права може використовуватися будь яка редакція Правил, оскільки нова редакція Йорк-Антверпенських правил не відміняє дію попередніх редакцій. А кількість редакцій Правил підтверджує їх важливість і необхідність при регулюванні цивільних відносин, які склалися у міжнародному приватному морському праві.

\section{Мітература}

1. Marine insurance law second edition. URL: https://books.google.com.ua/books?id $=3 \mathrm{ZY} 3 \mathrm{AAAAQBAJ} \&$ printsec $=$ frontcover $\& \mathrm{hl}$ $=\mathrm{ru} \&$ source $=$ gbs ge summary $\mathrm{r} \& \mathrm{cad}=0 \# \mathrm{v}$ $=$ onepage \&q\&f=false

2. Rudolf G. R. The York Antwerp Rules: Their history and development with comments on the rules of 1924. London. Stevens and Sons, Limited. 1926. 350 pages.

3. GENERAL AVERAGE A preliminary review Report by the UNCTAD secretariat. URL: https://unctad.org/system/files/officialdocument/c4isl58 en.pdf

4. THE YORK ANTWERP RULES. URL: Https://www.linkedin.com/pulse/yorkantwerp-rules-navin-kumar-jaggi
5. Сидоренко А. В. Чрезвычайные морские происшествия (правовые аспекты). Одесса. Латстар, 2001. 400с.

6. Т. Р. Короткий и др. Общая авария: международные и национальные стандарты. 2-е.изд. О.: Феникс, 2014. 145с.

7. CMI NEWS LETTER URL: https://comitemaritime.org/wp-content/ uploads/2018/05/N\%C2\%B01-2-JanuaryAugust-2016.pdf

\section{Shyshykin Sergii}

V.M. Koretsky Institute of State and Law of Natiopnal Academy of Sciences of UKRAINE HISTORICAL ANALYSIS OF THE YORK-ANTWERP RULES

The article presents a historical analysis of the York-Antwerp rules.

Attempts to codify the rules governing the general average are considered to be the beginning of 1860 , as a result of a letter from influential subjects of private international maritime law, the National Association for the Promotion of Social Sciences in London sent a letter to all maritime powers in Europe and the United States. As a result of this attempt, on September 25, 1860, discussions began in Glasgow on the codification of the rules of general average. As a result of these conferences, two resolutions were adopted and it was decided that 6 months should be given to draft a law and convene the next conference. However, the next conference was convened in June 1862. And due to certain difficulties, the issue of codification of the general average was not discussed.

The next discussion of the codification of the institute of general average took place only in 1864 in York. As a result, eleven York rules and a resolution were agreed upon. The York rules did not become widespread.

The question of unification of the norms of the general average was returned in 1877 in Antwerp, as a result of which the Rules adopted in York in 1864 were supplemented and renamed the York-Antwerp Rules, which after some time received initial recognition by the subjects. international private maritime law. 


\section{Цивільне, підприсмницьке, господарське та трудове право}

\section{АНОТАЦІЯ}

У статті представлений історичний аналіз Йорк-Антверпенських правил. Основна увага у статті приділена передумові та історіi створення Йорк-Антверпенських правил, підкреслена значна роль суб'єктів міжнародного приватного морсъкого права в унібікацй інституту загальної аварї̈, а також в статті розглянуті позитивне та негативне відношення суб'єктів міжнародного приватного морсъкого права, які виникли під час уніфікайї інституту загальної аварії. В результаmі дослідження матеріалів був підкреслений особливий статус та унікальність ЙоркАнтверпенсъких правил, передумови створення, змін та розвитку Правил, їх значна роль у регулюванні інституту зональної аварії на протязі великого проміжку часу.

Ключові слова: Йорк-Антверпенсъкі правила, Йорксъкі правила, унібікація інституту загальної аварій, конферениія в Глазго 1860 рочі, конферениія в Йорку 1864 рочі, Конферениія в Антверпені 1877 рочі.
As a result, it can be concluded that the York-Antwerp Rules are a unique source of private international maritime law, which gained its significance as a result of the voluntary use of these rules by subjects of private international maritime law. As mentioned above, at times the question of the mandatory implementation of the York-Antwerp Rules has been raised. In addition, another feature of the Rules is that subjects of private international maritime law may use any version of the Rules, as the new version of the York-Antwerp Rules does not repeal the previous versions. And the number of versions of the Rules confirms their importance and necessity in regulating civil relations that have developed in private international maritime law.

Key words: York-Antwerp Rules, York Rules, unification of the institute of general average, conference in Glasgow in 1860, conference in York in 1864, Conference in Antwerp in 1877 . 